\title{
Cross-Contaminations: On Schönberg's political beliefs and his music theoretical writings ${ }^{1}$
}

\begin{abstract}
This paper aims to show how Arnold Schönberg's political views permeate his theoretical writings and to a lesser degree even his musical works. Scholars usually point to works such as Ode to Napoleon Buonaparte or A Survivor from Warsaw, when discussing Schönberg's political thinking. Only seldom have scholars dealt with a more uncomfortable facet of this topic: Schönberg, for the longest time, was a convinced German nationalist. As late as 1931, ten years after the incident at Mattsee, he wrote Nationale Musik. In this short text, Schönberg tries to explain why German music is supposedly superior to that of other nations. In trying to prove his point, he uses many theoretical and analytical concepts, such as „Gedanke“, „Gestalt“, chromaticism, polyphony and homophony, „Themen und Sätze“, „Variation und Variierung“, etc. These terms and concepts are also continuously used in Schönberg's 'non-political' writings such as Harmonielehre (1911), Der musikalischeGedanke (1934-36) and Fundamentals of Composition (1937-48). This paper re-examines these texts critically and illustrates the cross-contamination between political beliefs and music theoretical thought within the writings of Schönberg.
\end{abstract}

Keywords: Schönberg, nationalism, polyphony, Gedanke, Gestalt.

Although, in a newspaper article of 1928, claiming to not being politically involved („I have nothing to do with politics and would like to keep inconsequential private opinions to myself ${ }^{\text {‘2 }}$ [Schönberg, 1928: 3]) $)^{3}$, Arnold Schönberg, called by the editor of this article „Führer der deutschenmusikalischen Modernen“ („leader of German musical modernism"), had been surprisingly vocal about political matters

1 This paper was originally presented at the $16^{\text {th }}$ International Conference on Music Theory in Rimini October 2019.

2 ,Mit Politik aber [...] habe ich nichts zu tun und möchte unmassgebliche Privatmeinungen gern für mich behalten dürfen."

3 This and all following translations by the author. 
throughout his life. This is especially true for, as it is labeled in the index of Schönberg's Nachlass ${ }^{4}$, 'Jewish affairs', but there also exist statements concerning e.g. the surge of fascism in the 1930s (See for example Über Macht, Mehrheit, Demokratie, Faschismus etc.- Schönberg, 1932) and, a rather uncomfortable facet of this topic and seemingly in opposition to the aforementioned, a multitude of letters, articles, and other writings giving expression to his German nationalistic beliefs. As late as 1931, ten years after the incident at Mattsee (See Waitzbauer, 2003), Schönberg wrote Nationale Musik. In this short text, he tries to explain why German music is supposedly superior to that of other nations. In trying to prove his point, he uses many theoretical and analytical concepts, such as „Gedanke“, „Gestalt“, chromaticism, polyphony and homophony, „,Themen und Sätze“, „Variation und Variierung“, etc. These terms and concepts are also continuously used in Schönberg's 'non-political' writings such as Harmonielehre (1911), Der musikalische Gedanke (1934-36) and Fundamentals of Composition (1937-48). This paper tries to illustrate the cross-contamination between political beliefs and music theoretical thought within the writings of Schönberg.

Few scholars, as it seems, have dealt with this topic. Hermann Danuser, in his text „Schönberg und die Idee einer deutschen Musik“, gives a broad overview. He identifies the roots of German nationalistic conceptions of art within the philosophy of Gottfried Herder. Danuser further explains how these conceptions influenced Schönberg's musical thought (,Musikdenken“) and how he - due to the rise of racial ideologies, the takeover of the National Socialist party, and his consequent emigration and reversion to Judaism, although superficially dissociating himself from any German nationalistic tendencies - never changed his „Musikdenken“: In his late writings he simply exchanged the labeling of music as 'German' with 'classical' (Danuser, 1997). „Max Reger und Arnold Schönbergs 'deutsche Musik' " by HarmutKrones on the one hand is far more polemical, on the other hand also delves much deeper into how Schönberg's concept of German music is expressed in his musical works. Krones achieves this by analyzing works by Max Reger as well as Schönberg. The main focus point of these analyses is the excessive usage of contrapuntal techniques and chromaticism in those works. But Krones also highlights in more detail the intricate conflict between Schönberg's nationalistic beliefs and his Jewishness. Additionally, although dealing with German as well as Zionist nationalism (!) only tangentially, Hanns-Werner Heister's text „Politik, Kunst, Religion: GewaltbeiSchönberg" should be mentioned. Heister works out how the complex field of violence is a constant theme not only in Schönberg's biography, but also in his artistic as well as theoretical works, and how this is intrinsically linked with his political and religious views (Heister, 2003: 54-56).

4 Schönberg's Nachlass is kept in the archive of the Arnold Schönberg Center Vienna. All the primary sources of this article can be found in that archive. 
It is important to understand, that Nationale Musik is by far not the only text by Schönberg trying to explain what characteristics and compositional techniques make music supposedly German. For this paper, in addition, Ostinato (1922), Volksmusik und Kunstmusik (1928), and Veraltete und NeueMusik (1932-33) are taken into consideration. In the following Schönberg's idea of cultural hegemony/conflict (1), as well as three music theoretical aspects (counterpoint/homophony (2), repetition/ variation (3) and the concept of 'Gedanke'/'Gestalt'/'Form'(4)), which can be found in these texts are being examined more closely: (1) Nationale Musik opens with: „Every nation can achieve hegemony in the field of arts. This does even not seem to hinge on economic or military superiority"5 (Schönberg, 1931: 1). In these opening sentences Schönberg unveils two main concepts, which are fundamental to the whole text and consecutively crucial for the understanding of the following examples from other texts. First one being the idea, that such thing as cultural hegemony does exist, second one that this hegemony is reached by other means than economic or military ones. Cultural hegemony, according to Schönberg, manifests itself when the cultural products of a 'race' or nation achieves a state, where, ,the whole remaining artistic world only knows one goal: to emulate this national art without asking how and to what extent it is actually achievable“" (Schönberg, 1931: 1-2). This hegemony is attained, as mentioned, not by economic or military means, but by ,the power of genius, the power of thought, the art of portrayal"“7 (Schönberg, 1931: 1). Especially 'Gedanke' and 'Kunst der Darstellung' are key-concepts in the theoretical writings by Schönberg and will be discussed in the following. Attaining but also preserving cultural hegemony supposedly implies conflict and even (cultural) war, as Schönberg points out. In the paragraph, for example, in which Schönberg deals with the perception of Richard Wagner's music outside of Germany, he deliberately uses terminology reminiscent of military language: "The music of Wagner was not only the best and most substantial of its time, surpassing not only that of Berlioz, Auber, Meyerbeer, Bizet, Rossini, Bellini and many more, but it was also the music of 1870s Germany, which, with all its merits conquered the world of its friends and its enemies [...]"8 (Schönberg, 1931: 6). Wagner's music conquered its friends and enemies. In the following, Schönberg concretises the idea of cultural conflict/war. „It was recognized however, that exporting cultural goods influences the economy advantageously and therefore, the liberation from the influence of Wagner's

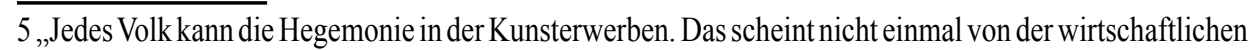
oder militärischen Uebermacht ab zu hängen.“

6 „Die gesamte übrige Kulturwelt nur ein Bestreben kennt: dieser nationalen Kunst nachzueifern, ohne dabei zu bedenken, ob und inwieweit ihr Vorbild erreichbar ist.“

7 ,Die Macht des Genies, die Macht des Gedankens, die Kunst der Darstellung.“

8 „Die Musik Wagners war nicht nur die beste und bedeutendste ihres Zeitalters, überragte nicht nur Berlioz, Auber, Meyerbeer, Bizet, Rossini, Bellini und a.m. sondern sie war auch die Musik des Deutschland von 1870, welches mit allen seinen Leistungen die Welt seiner Freunde und Feinde erroberte [sic!].“ 
music was the battle cry of musicians before the war“9 (Schönberg, 1931: 7). Here Schönberg furthermore introduces the concept, that there is a correlation between trade of cultural and commercial goods ${ }^{10}$ and also between 'cultural war' and the First World War. This becomes even more apparent in the following:

\begin{abstract}
„It is strange that it [the claim that Debussy's harmonic progressions being actually inventions by German composers] was never taken into account, [...] although the battle against German music during the war was primarily a battle against my music [...] - it is strange therefore, that no one has taken into account, that my music, which emerged on German grounds without the influence of foreign countries, is an art that, in the way it effectively opposes the Latin's and Slav's attempts at reaching hegemony, springs from the tradition of German music."11(Schönberg, 1931: 8-9)
\end{abstract}

This specific idea of being at war in order to reach/maintain cultural hegemony, especially with Schönberg himself at the frontlines does appear in numerous other texts. In Veraltete und NeueMusik, Schönberg uses the metaphor of a battlefield to describe rather sarcastically the conflict between 'neue' and 'veraltete' music: ,[...] we know almost as little about new music as its pioneers, if one can call the people from the musical hinterland, who, outside of the actual battlefront, vegetate in a parallel history, if one should call them pioneers" ${ }^{\text {"12 }}$ (Schönberg, 1932-33: 4). Similar ideas can be found almost one, respectively two decade(s) earlier in Harmonielehre. Already here Schönberg compares the conflict between modernism and conservatism with actual war: „Because new music is in need of being performed rather than defended, and the interest in repelling attacks diminishes, the more evident it becomes, how the attackers only destroy themselves, when they deploy criticism against work, impotence against power, sterility against productivity" ${ }^{\text {"13 }}$ (Schönberg, 2010: 488). And also, describing

9 „Aber man hatte erkannt, dass Export eines Kulturwertes den Export günstig beeinflusste und so war die Befreiung vom Einfluss der Wagnerschen Musik der Schlachtruf der Musiker vor dem Kriege."

10 The same concept can be found already in Harmonielehre where Schönberg casts a doubt on the theory, that the whole tone scale was 'imported' from East-Asia by the Russians and French (Schönberg, 2010: 467).

11 „Es ist merkwürdig, dass es noch nie beachtet wurde, [...] obwohl der Kampf den man während des Krieges gegen deutsche Musik führte, in erster Linie ein Kampf gegen die meinige war [...] - es ist also merkwürdig, dass noch niemand beachtet hat, dass in meiner Musik, die von [sic!] Ausland unbeeinflusst auf deutschem Boden entstanden ist, eine Kunst vorliegt, die, wie sie den Hegemoniebestrebungen der Romanen und Slawen aufs Wirksamste entgegentritt, durchaus den Traditionen der deutschen Musik entsprungen ist.“

$12,[\ldots]$ wir wissen beinahe noch ebensowenig [sic!] über die Neue Musik, wie ihre Vorkämpfer, wenn man die Leute aus dem musikalischen Hinterland, die ausserhalb der eigentlichen Kampffront in der Etappe der Geschichtsparallelen vegetieren, wenn man diese also Vorkämpfer nennen darf.“

13 „Denn die moderne Musik hätte es nötiger, aufgeführt als verteidigt zu werden, und das Interesse, die Angriffe abzuwehren, nimmt desto mehr ab, je augenfälliger es sich zeigt, wie die Angreifer nur sich 
his 'plan of attack' (which basically can be summarised as 'attack is the best form of defence'): „Since, according to good old military wisdom, every defence can be obtained by attacking, therefore a good defence almost is indistinguishable from attacking: [...] Here I openly and honestly attack with the intention to exterminate; not I am the defender but they are"14 (Schönberg, 2010: 489). It is important to emphasize that Schönberg's understanding of modernism and conservatism (which itself is a theme complex enough for its own paper) is inherently linked with his concept of cultural hegemony of a race or nation and therefore nationalism/chauvinism, which becomes apparent when looking at his delineation of counterpoint/homophony.

(2) Counterpoint and homophony are, according to Schönberg, two „main dimensions of musical art" ${ }^{\text {"15 }}$ (Schönberg, 1932-33: 2). They constitute a dialectical opposition. While one of the two ,is being worked on exclusively, the other is left behind, so that the next wave has to bring further development of the neglected dimension"16 (Ibid.) Schönberg claims, that Johann Sebastian Bach is a key figure not only for the cultural hegemony of 'Germany' (Schönberg, 1931: 2-3) but also in the 'conflict' between counterpoint and homophony. Schönberg agrees with the popular narrative, that contrapuntal music reached its culmination through Bach. At the same time, Bach supposedly can be partially considered as the inventor of motivic/ developing variation (Schönberg, 1931: 4, 5-6; and Schönberg, 1932-33: 5), which itself is the main feature of homophonic music („Homophonic music can be called the style of 'developing variation'“ [Schönberg, 1967: 8; see also Schönberg, 1934-36: 83]). But, ,the attempts to overthrow the art of the masters of counterpoint is initiated under the leadership of the Latins: Italian and French composers" ${ }^{\text {"17 }}$ (Schönberg, 1931: 3). Schönberg in addition points out, that it is surprising, that especially in the era of homophonic music, German hegemony became noticeable, although the homophonic style does not correspond with the „deutschen Wesen“ (,German character"), „denn Bach beweist das Gegenteil“" (,since Bach proves the opposite“ [Schönberg, 1931: 3]). This shows, that Schönberg seemingly deemed polyphonic music more German (and consequently probably superior).

selbst vernichten, wenn sie die Kritik gegen das Werk, die Ohnmacht gegen die Macht, die Sterilität gegen die Produktivität aufmarschieren lassen.“

14 „Wenn nun auch, nach alter guter militärischer Weisheit, jede Verteidigungsaufgabe angriffsweise gelöst werden, eine gute Verteidigung sich also vom Angriff kaum unterscheiden soll: [...] Hier greife ich offen und ehrlich an mit dem Willen, zu vernichten; nicht ich bin Verteidiger, sondern sie.“

15 „Hauptdimensionen der Tonkunst.“

16 „Ausschliesslich bearbeitet wird, bleibt die andere dermassen zurück, dass die nächste Welle dann die Weiterentwicklung der vernachlässigten Dimension bringen muss.“

17 „Die Umsturzbewegung gegen die Kunst der Meister des Kontrapunktes beginnt unter der Führung romanischer: italienischer und französischer Komponisten.“ 
Similar to the dialectic pair polyphony/homophony, Schönberg sees the aesthetic categories 'new' (,neue“) and 'outdated' (,veraltete“) music as, if you will, two sides of the same coin. He claims, that, while Bach was writing „Werk um Werke iner neuen Kunst" (,work after work of new art"), his surroundings ignored those works and ,ihre Neuheit“ (,their novelty“) and deemed other music 'modern'/"new' (Schönberg, 1932-33: 5). More than that, they (Bach's contemporaries) called his music ,veraltet“. But, according to Schönberg, ,two hundred years later the relations are opposite: what was regarded as new is outdated and Bach is eternal" ${ }^{\text {"18 }}$ (Schönberg, 1932-33: 6). This is mainly due to the fact, that Bach's music represents ,neuen Inhalt“" (,new content"), „,neue Gedanken“ (,new thoughts") and „neue Technik“ („new technique"), while the music of his contemporaries merely tried to utilise the whole „musikalischen Raum“ („musical space“) in a new way (Ibid.). Looking at Nationale Musik, it becomes evident, that Schönberg sees himself in the same position as Bach supposedly found himself in the past. After the 'invention' of composing with „12 nur auf einanderbezogenenTönen“(Schönberg, 1931: 6) (In this context it seems superfluous to mention the well-known remark(s) concerning German hegemony by Schönberg after 'inventing' the twelve-tone-method in 1921 [See also Schoenberg, 2003]) the way of writing of composers had to change unexpectedly and unpredictably, as it was the case after Bach. Furthermore, he understands the usage of all twelve tones as a new form of polyphony (,„harmonic] polyphony“199 [Schönberg, 1931: 5]). The whole text then concludes with following paragraph: „I am convinced that one will recognize in what is new, how it is intrinsically connected with the best, that which was given to us as an example. I claim the achievement of having written true new music, which in the same way is built upon tradition, will become tradition itself ${ }^{\mathrm{s} 20}$ (Ibid.: 11). Not only does Schönberg's dialectical thought become apparent in his juxtaposition of „neue Musik“ and „Tradition“, it is also striking how, although the Nationale Musik is about 'German hegemony' in music, Schönberg concludes not with the claim of having written „truly German music" but ,eine wahrhaft neueMusik“(,truly new music“). And, it would not be farfetched to think of interchanging ,neu“ respectively 'Deutsch' with 'polyphon', as these terms are evidently intertwined in Schönberg's „Musikdenken“.

(3) In Fundamentals Schönberg points out, that ,[V]ariations are primarily repetitions, which would become intolerable without constant restimulation of the listener's interest“ (Schönberg, 1967: 167). And in the chapter „Advice for Self-

18 ,Zweihundert Jahre später ist das Verhältnis umgekehrt: was als neu gegolten hat, ist veraltet und Bach ist bloss e w i g.“

19 ,(harmonische) Polyphonie“.

20 „Ich bin überzeugt, dass man einmal in diesem Neuen erkennen wird, wie innig es mit dem Besten verbunden ist, was uns als Vorbild gegeben war. Ich maße mir das Verdienst an, eine wahrhaft neue Musik geschrieben zu haben, welche, wie sie auf der Tradition beruht, zur Tradition zu werden bestimmt ist.“ 
Criticism“ he writes: „Too many repetitions of tones or melodic figures are annoying

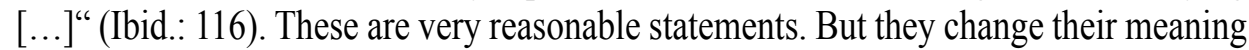
considerably, when one sheds a different light on them. In a handwritten note titled Ostinato from 1922 Schönberg writes the following:

„For me - this does not have to be true to anyone else - the first thing I expect from a work of art is: Richness! This meagreness of Latins and their Russian, Hungarian, English, American etc. imitators, even though it is supposed to be funny, is for me always ridiculous and tormenting. The method: to repeat a figure until $[\ldots]$ something intellectual emerges $[\ldots]$; this method reminds me very much of the humor of drunkards. [...] But every time one smiles about this: each time with less sympathy, and especially: with less respect! Instead increasingly the feeling of unease: the feeling of annoyance or even disgust! ‘21 (Schönberg, 1922: 1)

Especially in Der musikalische Gedanke Schönberg clearly constitutes a connection between 'repetition' and 'primitive'. E.g. „Repetition; endless, mostly unvaried repetition is the first and only method, by which primitive music can fill a time span longer than the duration of a motive“'22 (Schönberg, 1934-36: 63); and „Out of experience we know, that primitive music does not know any other way of continuation

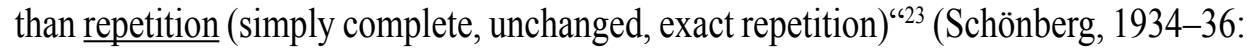
136). Although he never specifies what he sees as ,primitive Musik“, looking at Ostinato one can assume that Schönberg is alluding to the music of „Lateiner und ihrerrussischen, ungarischen, englischen, amerikanischen Nachahmer" - 'Latins' (which would be the French and Italians) and their Russian, Hungarian, English and American imitators.

(4) Schönberg states in Der musikalische Gedanke also, that „repetition of identical notes (which have the highest degree of coherence) do not create a Gestalt ${ }^{\text {“24 }}$ (Schönberg, 1934-36: 66). 'Gestalt', together with 'Gedanke' are some of the more

21 „Für mich - das braucht für keinen anderen wahr zu sein - ist das erste, was ich vom Kunstwerk erwarte:

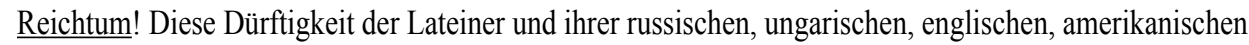
etc Nachahmer ist für mich, obwol [sic] sie oft komisch wirken soll, immer mehr lächerlich und peinigend. Diese Methode: eine Figur so lange zu wiederholen, bis sich [...] etwas ,Geistreiches ' herausstellt [...]; diese Methode erinnert mich zu sehr an den Humor der Betrunkenen [...]. Man lächelt allerdings jedesmal von Neuem über derlei; aber immer weniger Sympathie tut dabei mit, und insbesondere: immer weniger Achtung! Dagegen ein zunehmendes Missbehagen: Belästigungsgefühl bis Ekel!““

22 "Wiederholung; endlose, meist unvariierte Wiederholung ist das erste und einzig Mittel, mittels welchen die primitive Musik eine über die Dauer des Motivs hinausreichenden Zeitraum auszufüllen vermag"

23 "Aus der Erfahrung wissen wir, dass die primitive Musik keine andere Art von Fortsetzung kennt, als die Wiederholung (die einfach vollkommen unveränderte, getreue Wiederholung).“

24 „"[d]ie Wiederholung gleicher Töne (welche ja den größten Zusammenhang haben) erzeugt keine Gestalt." 
complex concepts in Schönberg's „Musikdenken“. As Christian Reineke has shown, Schönberg understands 'Gestalt' as a mean of expressing a 'Gedanke' (which harkens back to aforementioned concept of „Kunst der Darstellung“). Reineke presents 'Gestalt', 'Gedanke' and additionally 'Motiv' as elements of a hierarchical structure or gradiant: „Therefore, rhythmized sequences of tones become [...] main motives, the repetitions of these become main Gestalten, and these again constitute the basis of a mesh of variations, which encompass the whole work, and finally, this constitutes the epitome of a self-contained work of music “'25 (Reineke, 2007: 58, see also 56-58) The music piece in its entirety illustrates (as in 'darstellen') the 'Gedanke', or as Schönberg defines it: „How the main Gestalt changes under the influence of fighting forces within, $[\ldots]$ this constitutes the execution of the Gedanke, this is its Darstellung "2626 (Schönberg, 1934-36: 24). But it is important to understand, that the 'Gedanke' remains abstract, as Alexander Goehr describes it: „The conclusion we must draw is that the Idea is not of the tones themselves, in any particular order or combination, but that the tones cannot exist meaningfully without the hidden presence of the Idea" (Goehr, 1984: 62).

As already mentioned, according to Schönberg, the „Macht des Gedankens“ and the „Kunst der Darstellung“ are the means, by which cultural hegemony is achieved. Although, in Nationale Musik, never defining what the 'power of the idea' precisely is supposed to be, he explains accurately, through which techniques it is expressed, namely the composition techniques of Bach, Mozart, Beethoven, Wagner, Brahms and implicitly of course Schönberg himself. These techniques are mainly ways of creating or manipulating 'Gestalten'. But a 'Gedanke' can also be expressed through the wrong techniques, as Schönberg describes in Volksmusik und Kunstmusik, an unfinished manuscript written three years earlier than Nationale Musik. In Volksmusik und Kunstmusik, most of the themes from Nationale Musik are already anticipated, while the latter delves deeper into music theoretical questions, the former depicts political matters in greater detail. Interestingly, in the very first paragraph, Schönberg uses the concept of 'Gedanke' in a non-musical context. He speaks of the necessity of having superior ideas than other nations in as many fields as possible (,auf möglichstvielenGebieten um einenGedankenvorauszusein“ [Schönberg, 1925: 1]) in order to be able to produce export goods..$^{27}$ This would allow a nation to live of others (,auf Kosten der andernleben“). Art as an effective medium of propaganda is supposed

25 „Demgemäß würden rhythmisierte Tonfolgen [...], zum Grundmotiv, dessen Wiederholungen zur Grundgestalt, diese wiederum zum Ausgangspunkt eines [...] das Werkganze umfassenden Variationsgeflechtes und letzteres schließlich zum Innbegriff des in sich 'geschlossenen Musikstückes'.“ 26 ,Wie sich die Grundgestalt verändert unter dem Einfluss der in ihr kämpfenden Kräfte, [...] das ist die Durchführung des Gedankes [sic], das ist seine Darstellung."

27 A similar non-musical use of the concept of 'Gedanke' can be found in Veraltete und neue Musik. On p. 18 , he calls the mechanism of pliers a 'Gedanke'. 
to be an especially precious export good. Inferior nations therefore try to create their very own nationalistic art or more specifically (art) music in order to fight against the cultural hegemony of another nation. Schönberg claims, that this is most often done applying the techniques of the prevailing nations music onto the very own folk music. But, Schönberg concludes, this method yields a faulty outcome: „Although something can only become folkloric if it can be understood by everyone, being thought or expressed in a way, that everyone understands it, it is an important feature of higher Gedanken, that they cannot be understood without certain education of thought" ${ }^{\text {"28 }}$ (Schönberg, 1925: 2). Remarkably though, Schönberg does not specifically speak of German but of Western- and Central-European superiority in this text. It nevertheless is an explicit manifestation of his chauvinistic (and in consequence nationalistic) worldview.

Many of Schönberg's music theoretical concepts originate from non-musical contexts. As Goehr for example suggests, might 'Gedanke' be inspired by the writings of Karl Kraus (Goehr, 1984: 66).Another example would be 'liquidation', which originally is a term used in economics and chemistry (See Heneghan, 2019: 75-83).Therefore it does not come as a surprise that Schönberg also uses these and other concepts in his political writings. However, similar to the 'chicken or the egg'-dilemma, the direction of flow very often is not clear - are Schönberg's music theoretical writings inherently influenced by his political beliefs or are his political writings inherently influenced by his music theoretical thought? One would instinctively consider the latter to be more likely, but as the aforementioned examples show, even the 'early' Harmonielehreis already 'contaminated' with martial, militant, and chauvinistic conceptions. To a much lesser degree, this also can be said about the later music theoretical writings discussed in this paper. Schönberg's political views in his day were rather ordinary, and compared to, for example, those of his pupil Anton Webern rather tame (See e.g. Fiebig, 1995). Ernst Krenek went as far as calling the pupils of Schönberg „Pariahs [...] who lived the life of wild-eyed monks in a fanatic militant congregation" 29 (Quoted from Permoser, 2009: 530), although exactly this emanating fanatic, even militant aura described by Krenekcould be, what makes the Second Viennese School nowadays an appealing subject for such broad scholarly engagement. ${ }^{30}$ Nevertheless, it has to be emphasised that, looking at the current political landscape, German nationalism inexplicably still bears notable relevance, and therefore, still is a concern of current politics. In conclusion, taking the persistent strong influence of Schönberg's „Musikdenken“ on today's music theory into account, its rather uncomfortable aspects definitely should not be ignored.

\footnotetext{
28 „Während nämlich volkstümlich nur werden kann, was von allen erfasst werden kann, was also entweder so gedacht oder so gesagt ist, dass es jeder verstehen kann, ist es ein wesentliches Merkmal höherer Gedanken, dass sie kaum ohne eine gewisse Schulung des Denkens begriffen werden können.“ 29 „Ausgestoßene [...] [die] das Leben eines fanatischen, militanten Ordens gefährlicher, wildäugiger Mönche lebten."

$30 \mathrm{~A}$ fascination which still is seldom shared by concertgoers.
} 


\section{REFERENCES:}

\section{Primary Sources by Arnold Schönberg}

1. Schönberg, Arnold. 1922. Ostinato. T34.05. Arnold Schönberg Center, Vienna.

2. Schönberg, Arnold. 1925. Volksmusik und Kunstmusik. T36.07. Arnold Schönberg Center, Vienna.

3. Schönberg, Arnold. 1928. Fehlt der Welt eine Friedenshymne. T14.30. Arnold Schönberg Center, Vienna.

4. Schönberg, Arnold. 1931. Nationale Musik. T35.39. Arnold Schönberg Center, Vienna.

5. Schönberg, Arnold. 1932-33. Veraltete und neue Musik. T66.04. Arnold Schönberg Center, Vienna.

6. Schönberg, Arnold. 1932. Über Macht, Mehrheit, Demokratie, Faschismus etc. T 33.23. Arnold Schönberg Center, Vienna.

7. Schönberg, Arnold. 1934-36. Der musikalische Gedanke und die Logik, Technik und Kunst seiner Darstellung. T65.03. Arnold Schönberg Center, Vienna.

8. Schönberg, Arnold. 1967. Fundamentals of Musical Composition, edited by Gerald Strang and Leonard Stein, Pacific Palisades CA: Belmont Music Publishers.

9. Schönberg, Arnold. 2010. Harmonielehre, Vienna: Universal Edition.

\section{Secondary References}

1. Danuser, Hermann.1997. „Arnold Schönberg und die Idee einer deutschen Musik.“In Das Deutsche in der Musik, edited by Marion Demuth, 26-36. Dresden: Zentrum für zeitgenössische Musik, UniMedia.

2. Fiebig, Paul. 1995. „Einreden oder auch: Für und Wider. Anton Webern, Komponist, autoritärer Charakter." In Stil oder Gedanke? Zur Schönberg-Rezeption in Amerika und Europa, edited by Stefan Litwin and Klaus Velten, 126-136. Saarbrücken: Pfau.

3. Goehr, Alexander. 1984. „Schoenberg and Karl Kraus: The Idea behind the Music“, In: Music Analysis, Vol. 4, No. 1/2, Special Issue: King's College London Music Analysis Conference, 59-71.

4. Heister, Hanns-Werner. 2003. „Politik, Kunst, Religion: Gewalt bei Schönberg.“ In: Arnold Schönberg und sein Gott. Bericht zum Symposium 26.-29. Juni 2002, edited by Christian Meyer, 31-63. Vienna: Arnold Schönberg Center.

5. Heneghan, Áine. 2019. „Liquidation and Its Origins”, In: Journal of Music Theory 63:1, 71102.

6. Krones, Harmut. 2017. „Max Reger und Schönbergs 'deutsche Musik'. “In: Musikgeschichte in Mittel- und Osteuropa, Bd. 18, 326-352. Leipzig: Schröder.

7. Permoser, Manfred. 2009. „Sie lebten das Leben eines fanatischen, militanten Ordens gefährlicher, wildäugiger Mönche...' Krenek und der Schönberg-Kreis - Stationen einer Annäherung." In: Bungardt, Julia (ed.), Wiener Musikgeschichte: Annäherungen - Analysen Ausblicke. Festschrift für Harmut Krones, edited by Julia Bungardt, 527-539. Vienna: Böhlau.

8. Reineke, Christian. 2007. Der musikalische Gedanke und die Fasslichkeit als zentrale musiktheoretische Begriffe Arnold Schönbergs (=Kölner Beiträge zur Musikwissenschaft Band 10), Kassel: Bosse.

9. Schoenberg, E. Randol. 2003. „The Most Famous Thing He Never Said.“In: Arnold Schönberg 
und sein Gott. Bericht zum Symposium 26.-29. Juni 2002, edited by Christian Meyer, 27-30. Vienna: Arnold Schönberg Center.

10. Waitzbauer, Harald. 2003. „Arnold Schönberg und das Mattsee-Ereignis.” In: Arnold Schönberg und sein Gott. Bericht zum Symposium 26.-29. Juni 2002, edited by Christian Meyer, 14-26. Vienna: Arnold Schönberg Center.

\section{Unakrsna kontaminacija: o Šenbergovim političkim uverenjima i njegovim muzičko-teorijskim napisima ${ }^{31}$}

Apstrakt: Ovaj rad ima za cilj da pokaže kako politički pogledi Arnolda Šenberga prožimaju njegove teorijske napise, a u manjoj meri čak i njegova muzička dela. Kada govore o Šenbergovom političkom razmiljanju, stručnjaci obično ukazuju na njegove kompozicije „Oda Napoleonu Bonaparti“ ili „Preživeli iz Varšave.“ Tek retko se bave manje ugodnim aspektom ove teme: Šenberg je veoma dugo bio pristalica nemačkog nacionalizma. Još 1931. godine, deset godina nakon incidenta u gradu Matze, napisao je Nationale Musik [Nacionalna muzika]. U ovom kratkom tekstu, Šenberg pokušava da objasni zašto je nemačka muzika navodno superiornija od muzike drugih naroda. U pokušaju da dokaže svoje stavove, on koristi mnoge teorijske i analitičke koncepte, poput „Gedanke“ [Misao], „Gestalt" [Geštalt], hromatizma, polifonije i homofonije, „Themen und Sätze“ [Teme i rečenice], „Variation und Variierung“ [Varijacija i variranje], itd. Ovi pojmovi i koncepti se takođe kontinuirano koriste u Šenbergovim „nepolitičkim“ napisima kao što su Harmonielehre [Harmonija] (1911), Der musikalische Gedanke [Muzička misao] (1934-36) i Osnovi kompozicije (1937-48). Ovaj rad kritički preispituje ove tekstove i ilustruje unakrsnu kontaminaciju političkog uverenja i muzičko-teorijske misli unutar Šenbergovih napisa.

Ključne reči: Šenberg, nacionalizam, polifonija, Gedanke, Gestalt.

31 Ovaj rad je prvobitno predstavljen na 16. Međunarodnoj konferenciji o teoriji muzike u Riminiju 2019. godine. 